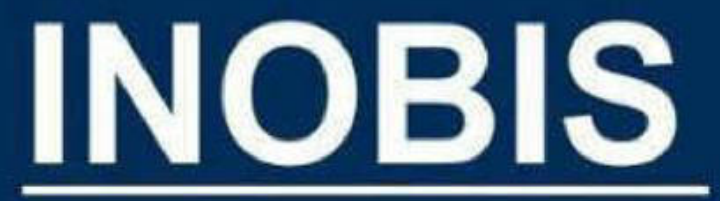

\title{
JURNAL INOVASI BISNIS DAN MANAJEMEN INDONESIA
}

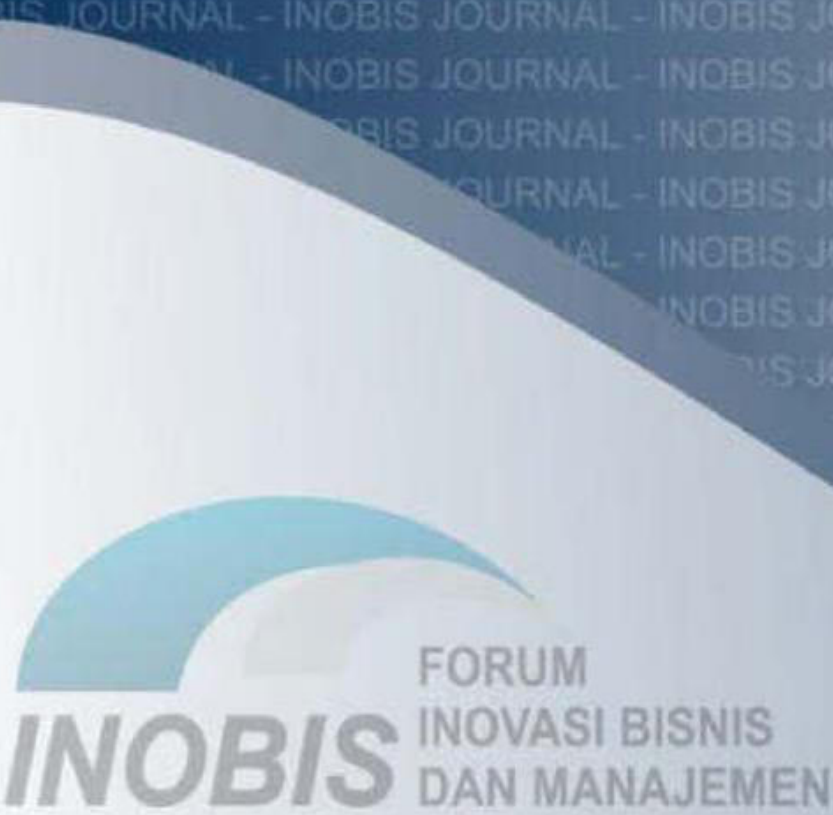




\section{Jurnal Inovasi Bisnis dan Manajemen Indonesia}

ISSN, 2614-0462 (Online)

Volume 4, No. 3, Juni 2021

\section{Daftar Isi}

305-315 Pengaruh Beban Pajak Tangguhan dan Perencanaan Pajak Terhadap Manajemen Laba

Dita Rimbawati Dewi, Dian Anita Nuswantara

316-325 Kajian Conditional Beta di Bursa Efek Indonesia

Yuvica Lara Rovantiane, Robiyanto

326-345 Pengaruh Green Perceived Value, dan Green Perceived Risk terhadap Green Repurchase Intention, dengan Green Trust sebagai Variabel Mediasi (Survei pada Masyarakat Kota Ternate yang Menggunakan BBM Jenis Pertalite pada Kendaraan Bermotor)

Ardhy La Mada, Ida Hidayanti, Ibnu Sina Hi. Yusuf

346-360 Stimulus Iklan, Positive Electronic Word of Mouth (eWOM) dan Belanja Impulsif: Dampak Mediasi Motif Hedonis Pembelanja Online Nani Ernawati

361-374 Pengaruh Kualitas Produk, Gaya Hidup, dan Pengetahuan Produk terhadap Proses Keputusan Pembelian Sepeda Lipat di Kota Semarang Yusuf Bagus Prakosa, Endang Tjahjaningsih

375-388 RBV Teori : Kinerja Religius Berbasis Kepribadian Islam dan Perilaku Inovatif Dalam Konseptual

Ali Jufri, Pebi Kurniawan, Mohammad Djadjuli, Imam Hadiwibowo

389-395 The Impact Of Competency, Workload, and Work Environment to Work Stress and The Employee Performance of Bank BJB S. Parman Indyra Dwi Cahyaningtyas, Allicia Deana Santosa

396-408 Perbandingan Kinerja Keuangan BUSN Devisa Konvensional dan BUSN Non Devisa Konvensional

Ma'ulvi Marsela Devi , Evi Sistiyarini

409-423 Penerapan Work From Home terhadap Produktivitas Kerja (Studi Karyawan Pt Berlian Jasa Terminal Indonesia) Julika Pasaribu, Mochammad Isa Anshori

424-436 Pengaruh Word Of Mouth dan Manfaat Terhadap Keputusan Menggunakan E-Wallet Dana Melalui Kepercayaan Pelanggan di Jabodetabek Ditiya Himawati, Mu'minatus Fitriati Firdaus

437-449 Upaya Peningkatan Keunggulan Bersaing Usaha Mikro Kecil dan Menengah (UMKM) di Kota Medan di Masa Pandemi Covid 19 Esty Pudyastuti, Ahmad Saputra 


\title{
Pengaruh Beban Pajak Tangguhan dan Perencanaan Pajak Terhadap Manajemen Laba
}

\author{
Dita Rimbawati Dewi \\ Universitas Negeri Surabaya \\ Dian Anita Nuswantara \\ Universitas Negeri Surabaya \\ ditarimbawatidewi@gmail.com
}

\begin{abstract}
Abstrak
This study aims to examine the effect of deferred tax expense and tax planning on earnings management. This research is a quantitative study using secondary data from financial reports and annual reports of manufacturing companies sub-sector consumer good indutry listed on the Indonesia Stock Exchange from 2014 until 2018. The sample selection uses a purposive sampling method. Data analysis techniques using multiple regression analysis with SPSS 23. The results of this study are the variable tax planning has a positive influence on earnings management. The variable deferred tax expense does not have a significant effect on earnings management because management has limitations in determining the amount of deffered tax expense.
\end{abstract}

Kata Kunci: Deferred Tax Expense; Tax Palnning, Earning Management; Consumer Goods Industry

\section{Pendahuluan}

Laba perusahaan diperhitungkan sebagai informasi penting bagi para pemangku kepentingan seperti investor, kreditur serta pemilik perusahaan. Namun, praktik manajemen laba telah menurunkan informasi laba guna menentukan keputusan (Cohen et al., 2005). Dari Wareza (2019) diketahui bahwa laporan keuangan PT Tiga Pilar Sejahtera Food Tbk tahun buku 2017 disajikan ulang pada tahun 2020, termasuk laporan keuangan 2018 dan 2019 yang ketika itu belum dilaporkan. Perusahaan membukukan rugi bersih Rp 5,23 triliun sepanjang 2017, pada laporan keuangan yang telah di-restatement tersebut. Jumlah ini lebih besar Rp 4,68 triliun dari laporan keuangan versi sebelumnya yang hanya rugi $\mathrm{Rp} 551,9$ miliar. Besarnya rugi tersebut terjadi karena penggelembungan pada pos piutang usaha, persediaan dan aset. Kasus ini menunjukkan bahwa perusahaan melakukan praktik manajemen laba yang mengakibatkan laporan keuangan misleading. Karena pemegang saham tidak memiliki informasi sebagaimana informasi yang dimiliki oleh manajemen (agent) atau dikenal sebagai asimetrik informasi (Lisa, 2012). Kondisi ini menyebabkan agent termotivasi untuk menggunakan kesempatan yang dimiliki untuk melakukan praktik manajemen laba (Mahpudin, 2017).

Motivasi untuk memanfaatkan kesempatan ini semakin besar ketika standar akuntansi menyediakan pilihan atas metode yang digunakan perusahaan untuk membuat laporan keuangan. Berbeda dengan standar akuntansi, pelaporan untuk tujuan perpajakan memiliki kelonggaran yang lebih sedikit karena adanya tujuan pemerintah untuk mengekang motivasi wajib pajak untuk menurunkan pembayaran pajaknya (Nurhandono \& Firmansyah, 2017). Satu sisi, manajemen memiliki kesempatan untuk menerapkan manajemen laba, namun di sisi lain manajemen tidak dapat secara leluasa memilih alternative metode untuk keperluan pajak 


\section{Dita Rimbawati Dewi, Dian Anita Nuswantara}

(Aditama \& Purwaningsih, 2014), dengan demikian terdapat trade-off di antara keduanya. Dengan kata lain, meskipun perusahaan dapat dengan leluasa melakukan praktik manajemen laba, namun tidak pada laporan pajak. Perbedaan antara laporan keuangan untuk tujuan umum dan tujuan pajak dapat mengindikasikan seberapa besar perusahaan sebagai wajib pajak menyesuaikan labanya untuk kepentingan manajemen. Meskipun telah banyak penelitian mengenai Pengaruh Beban Pajak Tangguhan dan Perencanaan Pajak terhadap Manajemen Laba, namun topik ini masih perlu untuk diteliti kembali. Karena, berbagai upaya pemerintah untuk mengintegrasikan kedua kepentingan masih selalu diupayakan, namun belum dapat menyelaraskan secara penuh sehingga masih terbuka kesempatan perusahaan untuk melakukan manajemen laba (Prabowo, 2020).

Penelitian terdahulu telah menemukan berbagai faktor yang memengaruhi manajemen laba, diantaranya termasuk beban pajak tangguhan dan perencanaan pajak (Achyani \& Lestari, 2019). Beban pajak tangguhan dapat mempengaruhi manajemen laba dengan penundaan pengakuan penghasilan dan mempercepat pengakuan beban untuk menghemat pajak sehingga laba yang dilaporkan lebih kecil (Lubis \& Suryani, 2018). Sedangkan perencanaan pajak adalah cara untuk menggunakan berbagai kesempatan bagi perusahaan guna menentukan aturan perpajakan, supaya perusahaan tersebut membayarkan kewajiban pajaknya seminimal mungkin (Suandy, 2016). Kedua faktor tersebut telah diteliti oleh Sumomba \& Hutomo (2012) dan hasilnya menunjukkan bahwa perencanaan pajak dan beban pajak tangguhan mempengaruhi manajemen laba. Namun penelitian tersebut telah dilakukan 10 tahun yang lalu dimana peraturan perpajakan maupun standar akuntansi telah mengalami perubahan yang cukup banyak. Sehingga, penelitian yang terkini dilakukan oleh Achyani \& Lestari (2019) memberikan hasil yang berbeda, bahwa beban pajak tangguhan dan perencanaan pajak tidak mempengaruhi manajemen laba. Kondisi yang terus berubah, keinginan pemerintah untuk terus menyelaraskan akuntansi dan pajak yang masih belum tercapai, menyebabkan peneliti ingin melakukan penelitian kembali terkait tema yang sama.

\section{Landasan Teori dan Pengembangan Hipotesis}

\section{Teori Keagenan.}

Jensen \& Meckling (1976) menjelaskan, teori agency ialah teori yang mengulas hubungan antara pihak principal dengan agent. Pihak prinsipal melimpahkan otoritas kepada agent untuk mengelola perusahaan. Sebagai pengelola, pihak manajemen lebih banyak memiliki informasi tentang perusahaan saat ini maupun prospek bisnis mendatang dibandingkan para pemegang saham. Oleh karena itu, dalam pengambilan keputusan, pemegang saham sangat bergantung pada informasi yang dipublikasikan oleh manajemen. Namun, secara alamiah, manajemen memiliki kepentingan yang berbeda dengan para pemegang saham. Eisenhardt (1989) menjelaskan terdapat tiga sifat manusia dalam teori keagenenan yakni: (1) pribadi yang mementingkan diri sendiri (self interest); (2) pribadi yang memiliki daya pikir terbatas mengenai persepsi masa datang (bounded rationality); (3) pribadi yang menghindari risiko (risk averse). Dari sifat tersebut, manajemen akan mengedepankan kepentingan dirinya terlebih dahulu. Hal inilah yang mendorong manajemen sebagai agen untuk menggunakan pengetahuannya untuk menggunakan angka-angka akuntansi untuk memenuhi keinginannya, termasuk mempublikasikan informasi yang tidak sesuai dengan fakta dalam perusahaan. Situasi seperti ini dikenal dengan nama asimetri informasi (Wibisono, 2014).

Berkaitan dengan pajak, manajemen sebagai wajib pajak memiliki pandangan bahwa pajak adalah beban yang harus ditanggung dan dapat mengurangi laba perusahaan, sehingga ia 


\section{Dita Rimbawati Dewi, Dian Anita Nuswantara}

cenderung melaporkan pajak serendah-rendahnya (Nugraha \& Meiranto, 2015). Manajemen berkepentingan untuk meningkatkan arus uang masuk dan menurunkan arus uang keluar, termasuk pembayaran pajak. Dengan melaporkan pajak yang rendah, maka manajemen juga membayar pajak yang rendah. Namun di sisi lain, melaporkan pajak yang rendah identik dengan laba yang rendah pula. Hal ini bertentangan dengan kepentingan pemegang saham terhadap laba yang tinggi, karena laba tinggi menjadi indikator kinerja yang baik di masa mendatang. Oleh karena itu, manajemen akan mengatur laba untuk memenuhi kepentingan yang menjadi prioritas mereka. Dalam kondisi ini manajemen adalah pihak yang memiliki informasi yang lebih banyak yang memungkinkan manajemen melaksanakan manajemen laba (Richardson, 1998).

\section{Manajemen Laba}

Manajemen laba memiliki definisi beragam. Fahmi (2013) mendefinisikan manajemen laba (earnings management) sebagai suatu cara yang menyesuaikan keuntungan sesuai yang dikehendaki oleh kelompok tertentu, khususnya pihak company management. Dyreng, Hanlon, \& Maydew (2011) lebih memfokuskan definisi manajemen laba sebagai daya upaya yang dimanfaatkan manajer perusahaan untuk memengaruhi angka profit bersistem dan terencana dengan menetapkan kebijakan dan prosedur tertentu dari standar akuntansi legal yang secara ilmiah dapat mengoptimalkan nilai pasar perseroan. Sedangkan Lestari (2018) manajemen laba merupakan upaya dalam pelaporan laba perusahaan dalam periode tertentu yang telah dilakukan pihak manajemen dengan sengaja untuk maksud tertentu tetapi masih berdasarkan koridor/metode akuntansi yang diterima umum. Menurut Astutik \& Mildawati (2016) manajemen laba dapat diterapkan apabila manajer benar-benar mempertimbangkan pelaporan keuangan dan pembuatan transaksi guna memanipulasi laporan keuangan terkait jumlah keuntungan dan kinerja perusahaan kepada stakeholder guna memengaruhi hasil perjanjian ataupun besaran bonus manajer yang tergantung pada keberhasilan dan jumlah keuntungan yang dilaporkannya.

\section{Beban Pajak Tangguhan}

Harnanto (2013) mendefinisikan beban pajak tangguhan sebagai tangguhan yang muncul karena dampak perbedaan temporer antara laba akuntansi (laba pada laporan keuangan bagi pihak luar) dengan laba fiskal (laba untuk pedoman menghitung beban pajak). Beban pajak tangguhan terjadi karena terdapat selisih sehingga pengeluaran dan penghasilan tahun sebelumnya akan diakui pada tahun berikutnya. Beda temporer ialah perbedaan yang diakibatkan terdapatnya perbedaan waktu, tata cara pengakuan pendapatan dan beban tertentu bersumber standar akuntansi dan peraturan perpajakan (Suandy, 2016). Beban pajak tangguhan menurut Lestari (2018) ialah total pajak pendapatan yang terutang atau dapat terpulihkan pada periode selanjutnya yang disebabkan oleh terdapatnya perbedaan temporer yang dapat dikurangkan dari sisa kompensasi kerugian yang bias dikompensasikan. Sedangkan menurut Barus \& Setiawati (2015) beban pajak tangguhan merupakan komponen dari keseluruhan beban pajak pendapatan yang mencerminkan adanya perbedaan temporer antara laba buku dengan penghasilan kena pajak.

\section{Perencanaan Pajak}

Pohan (2013) menyatakan bahwa perencanaan pajak yaitu upaya mengorganisasi usaha WP orang individu ataupun badan usaha dengan mempergunakan bermacam cela yang bisa dilakukan oleh WP dalam ketentuan peraturan perpajakan, supaya WP sanggup membayar pajak pada total paling rendah. Bagi Suandy (2016) perencanaan pajak yakni langkah pertama pada manajemen pajak. Saat tingkatan ini dilaksanakan penghimpunan serta riset terhadap 


\section{Dita Rimbawati Dewi, Dian Anita Nuswantara}

peraturan perpajakan supaya bisa dipilih tipe tindakan penghematan yang hendak diterapkan. Pada prinsipnya perencanaan pajak berfungsi meminimalkan kewajiban pajak terutang yang harus dibayarkan. Menurut Febrian et al. (2018) perencanaan pajak merupakan tindakan yang merujuk pada proses merekayasa upaya khususnya transaksi wajib pajak supaya hutang pajaknya dapat ditekan semaksimal mungkin namun tetap mengikuti aturan perpajakan, dengan demikian perencanaan pajak ialah tindakan legal atau diperbolehkan selama masih dalam koridor peraturan perpajakan yang berlaku di Indonesia. Selain perihal tersebut, wajib pajak perusahaan diharuskan membuat laporan keuangan dengan berlandaskan peraturan perpajakan sehingga timbulnya perbedaan antara PSAK dengan peraturan pajak menghasilkan nilai laba yang berbeda, yakni laba sebelum pajak (keuntungan akuntansi berdasarkan peraturan akuntansi yang berlaku) dan pendapatan kena pajak (jumlah laba fiskal dihitung berdasarkan peraturan fiskal).

\section{Pengembangan Hipotesis}

\section{Pengaruh Beban Pajak Tangguhan terhadap Manajemen Laba}

Astutik (2016) menjelaskan bahwa pada prinsipnya beban pajak tangguhan merupakan dampak dari pajak masa datang yang disebabkan oleh waktu antara perlakuan akuntansi dengan perpajakan sehingga kerugian fiskal dapat dikompensasikan pada periode tertentu. Beban pajak tangguhan yaitu pajak dikarenakan adanya perbedaan dalam pengakuan pendapatan atau beban antara peraturan perpajakan (fiskal) dengan standar akuntansi komersial (Scott, 2000). Astutik (2016) juga menjelaskan metode pajak tangguhan merupakan metode akuntansi yang memiliki hubungan erat dengan kebijakan akrual yang telah ditetapkan manajamen. Perusahaan diwajibkan untuk mengevaluasi manfaat atau kewajiban perpajakan yang ditangguhkan secara periodik. Jika pertimbangan suatu aktiva atau kewajiban pajak tangguhan bersifat subjektif sehingga manajemen dapat memanfaatkan kondisi tersebut untuk melakukan praktik manajemen laba. Pajak dapat dijadikan sebagai motivasi manajemen perusahaan untuk melakukan manajemen laba dengan cara memperkecil taxable income untuk mengurangi pajak dengan menggunakan metode akuntansi dalam perhitungan nilai persediaan, depresiasi dan cadangan lainnya yang diperbolehkan (Scott, 2003 dalam Astutik,2016). Sehubungan dengan Agency Theory yang mengakibatkan selisih info antara agent dan owner dapat memberikan peluang bagi manajer guna melaksanakan penerapan manajemen laba. Hal tersebut pula didukung dengan terdapatnya keleluasaan yang diperbolehkan oleh SAK kepada WP guna menetapkan prosedur akuntansi untuk membuat pelaporan keuangan mendukung manajemen dalam menetapkan metode akuntansi dalam menyusun laporan keuangan tersebut. Semakin kecil pajak tangguhan maka semakin selaras antara aturan pajak dengan komersial sehingga kesempatan manajemen melaksanakan penerapan manajemen laba menjadi lebih kecil (Putra, Sunarta, \& Fadillah, 2018). Hal ini didukung dengan penelitian Sumomba \& Hutomo (2012), Kisno \& Istianingsih (2016) yang menunjukkan bahwa manajemen laba dipengaruhi positif oleh pajak tangguhan

$\boldsymbol{H}_{1}$ : Beban pajak tangguhan berpengaruh positif terhadap manajemen laba

\section{Pengaruh Manajemen Pajak terhadap Manajemen Laba}

Berkaitan dengan teori agensi yaitu hubungan antara pihak manajerial dengan investor dan pemerintah. Hal ini menimbulkan konflik kepentingan antara pihak manajemen perusahaan dengan pemerintah sehingga mendorong pihak manajemen untuk melakukan perencanaan pajak (Santana \& Wirakusuma, 2016). Pihak manajemen perusahaan (agen) melaksanakan upaya penyetoran pajak serendah-rendahnya supaya laba yang diterima perusahaan setelah penyetoran pajak dapat maksimal sedangkan pemerintah (principal) 


\section{Dita Rimbawati Dewi, Dian Anita Nuswantara}

melakukan upaya agar pembayaran pajak yang sesuai dengan keadaan perusahaan yang sebenarnya karena pajak merupakan sumber penerimaan negara (Aditama \& Purwaningsih, 2014). Hal ini menyebabkan permasalahan kepentingan antara pihak manajemen perusahaan (agen) dengan pemerintah (principal) sehingga dapat mendorong pihak manajemen perusahaan (agen) untuk melaksanakan perencanaan pajak. Perusahaan melakukan perencanaan pajak dengan sesuai maka berimbas terhadap pengurangan laba melalui beban perpajakan perusahaan tersebut (Yunila \& Aryati, 2018). Hal ini sejalan dengan penelitian Sumomba \& Hutomo (2012), Lubis \& Suryani (2018), Khotimah (2014) dan Febrian, Wahyudi, \& Subeki (2018) dalam penelitiannya memiliki hasil bahwa manajemen laba dipengaruhi positif oleh perencanaan pajak

$\boldsymbol{H}_{2}$ : Perencanaan pajak berpengaruh positif terhadap manajemen laba

\section{Metode Penelitian}

Studi ini merupakan riset kuantitatif. Menurut Sugiyono (2015) riset kuantitatif ialah riset pada populasi atau sampel, instrument riset sebagai media untuk mengumpulkan data, analisa data bersifat statistika guna membuktikan hipotesis yang sudah ditentukan. Data riset diperoleh dari laporan keuangan masing-masing perusahaan manufaktur sektor barang konsumsi tertera di Bursa Efek Indonesia (BEI) tahun 2014-2018. Data tersebut termasuk data sekunder yang didapatkan dari sumber kedua. Penelitian ini bertujuan untuk menguji kembali regulasi pemerintah bidang perpajakan yang berusaha menyelaraskan kepentingan wajib pajak dan pemerintah. Oleh karena itu, penelitian ini menggunakan Teknik nonprobability sample sesuai kriteria tertentu yang disebut purposive sampling (Cooper \& Schindler, 2014). Kriteria yang telah ditetapkan oleh penulis untuk menentukan jumlah sampel studi dari perusahaan manufaktur bidang industri barang konsumsi yang tercatat di BEI yang mempublikasikan laporan keuangannya yang telah diaudit dan laporan tahunan selama berturut-turut periode 2014-2018. Alasan pemilihan sampel karena pada sektor perusahaan tersebut terdapat kasuskasus terkait manajemen laba seperti yang dijelaskan pada pendahuluan. Sampel keseluruhan dalam penelitian ini adalah 95 sampel.

\section{Variabel Penelitian dan Definisi Operasional}

Variabel terikat pada riset ini ialah manajemen laba. Menurut Fahmi (2013) earning management ialah sesuatu upaya yang mengatur laba berdasarkan kemauan oleh golongan tertentu atau (company management). Dalam riset ini rumusan variabel dependen yang ditetapkan berdasarkan Phillips, Pincus, \& Rego (2003).

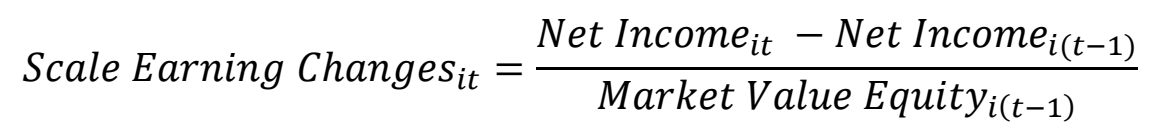

Variabel bebas pada studi ini yakni beban pajak tangguhan dan perencanaan pajak. Studi ini menggunakan rumus beban pajak tangguhan seperti yang diterapkan dalam penelitian Sumomba \& Hutomo (2012). Sedangkan variabel perencanaan pajak ditentukan menggunakan rumus Tarif Pajak Efektif (Sandy \& Lukviarman, (2015). Tarif Pajak Efektif ini diperoleh dengan rumus pembagian beban pajak dengan laba sebelum pajak.

\section{Teknik Pengumpulan dan Analisis Data}

Metode dokumentasi merupakan metode yang dipakai dalam pengumpulan data studi ini. Metode dokumentasi berbentuk laporan keuangan dari masing-masing perusahan yang menjadi sampel peneltian. Sedangkan analisis data penelitian ini menggunakan teknik analisis regresi berganda dengan software SPSS 23. Analisis data pertama dengan pengujian asumsi 
klasik yang terdiri dari uji normalitas, uji autokorelasi, uji multikolinearitas, dan uji heterokedastisitas. Selanjutnya adalah uji analisis berganda, uji simultan, uji parsial, dan uji koefisien determinasi $\left(\mathrm{R}^{2}\right)$.

\section{Pembahasan}

\section{Analisis Statistik Deskiptif}

Tabel 1. Analisis Statistik Deskriptif

\begin{tabular}{|l|c|c|c|c|c|}
\hline & $\mathrm{N}$ & Minimum & Maximum & Mean & $\begin{array}{c}\text { Std. } \\
\text { Deviation }\end{array}$ \\
\hline EM & 95 & -.008 & .016 & .00267 & .005306 \\
\hline TRR & 95 & .210 & .290 & .25042 & .018675 \\
\hline BBPT & 95 & -.008 & .009 & .00043 & .003763 \\
\hline Valid N(listwise) & 95 & & & & \\
\hline \multicolumn{7}{|c|}{ Sumber: Output SPSS }
\end{tabular}

Sesuai tabel satu di atas menunjukkan hasil uji statistik deskriptif dengan menggunakan sampel setelah uji normalitas sehingga menghasilkan jumlah sampel sebanyak 95 sampel data. Dari tabel analisis statistik deskriptif di atas nilai tertinggi untuk variabel earnings management (EM) 0.016 dimiliki oleh PT Ultra Jaya Milk Industry sedangkan nilai terendah -0.008 dimiliki oleh PT Sekar Bumi dan nilai rata-rata 0.00267. Variabel dependen pertama perencanaan pajak (TRR) memiliki nilai maksimum 0.290 pada PT Darya Varia Laboratoria, nilai minimum 0.210 dan nilai rata-rata sebesar 0.25042. Variabel dependen kedua beban pajak tangguhan (BBPT) memiliki nilai terendah -0.008 , nilai tertinggi 0.009 dan nilai mean 0.00043 .

\section{Uji Asusmsi Klasik}

Pada tabel dua nilai uji normalitas didapat dari hasil uji Kolmogorov-Smirnov yang memiliki nilai yaitu 0,200. Nilai itu mengartikan variabel-variabel dalam riset telah lolos normalitas disebabkan melebihi nilai signifikansi yakni melebihi 0.05. Runs Test berguna dalam riset ini untuk mendeteksi hasil tes auotokorelasi. Riset ini terhindar dari autokorelasi karena hasil uji Runs Test bernilai 0.257. Nilai tersebut melebihi nilai signifikasi sebesar 0.05. Sehingga dinyatakan studi ini lolos uji autokorelasi. Uji heterokedastisitas yang digunakan riset ini dengan uji glejser. Penelitian dapat dikatakan lolos uji heterokedastisitas apabila hasil uji glejser melebihi nilai signifikansi yang ditetapkan yakni 0,05 (Ghozali, 2016). Hasil tes glejser untuk variabel perencanaan pajak (TRR) 0.610 dan untuk variabel beban pajak tangguhan (BBPT) sebesar 0.269. Nilai uji glejser untuk kedua variabel dependen telah melebihi nilai signifikansi yaitu lebih dari 0,05 maka diartikan riset ini telah lolos uji heterokedastisitas. Tes asumsi klasik terakhir adalah uji multikolinearitas. Nilai VIF dan nilai tolerance merupakan nilai untuk mengetahui hasil uji multikolinearitas. Nilai VIF untuk kedua variabel independen yakni variabel perancanaan pajak (TRR) dan beban pajak tangguhan (BBPT) bernilai 1.007 dan nilai tolerance kedua variabel independen sebesar 0.929. Nilai tolerance pada variabel independen penelitian ini melebihi 0.10 serta nilai VIF tidak melebihi 10 maka studi ini terhindar dari gejala multikolinearitas.

Tabel 2. Hasil Uji Asumsi Klasik

\begin{tabular}{|l|c|c|c|}
\hline \multicolumn{1}{|c|}{ Jenis Pengujian } & EM & TRR & BBPT \\
\hline Uji Normalitas & \multicolumn{3}{|c|}{0.200} \\
\hline Hasil Uji & \multicolumn{3}{|c|}{ Sig } \\
\hline Simpulan &
\end{tabular}


INOBIS: Jurnal Inovasi Bisnis dan Manajemen Indonesia

Volume 04, Nomor 03, Juni 2021

Dita Rimbawati Dewi, Dian Anita Nuswantara

\begin{tabular}{|c|c|c|}
\hline \multicolumn{3}{|l|}{ Uji Autokorelasi } \\
\hline Hasil Uji & \multicolumn{2}{|c|}{0.257} \\
\hline Simpulan & \multicolumn{2}{|l|}{ Sig } \\
\hline \multicolumn{3}{|c|}{ Uji Heterokedastisitas } \\
\hline Hasil Uji & 0.610 & 0.269 \\
\hline Simpulan & Sig & Sig \\
\hline \multicolumn{3}{|c|}{ Uji Multikolinearitas } \\
\hline Nilai VIF & 1.007 & 1.007 \\
\hline Nilai Tolerance & 0.929 & 0.929 \\
\hline Simpulan & Sig & Sig \\
\hline
\end{tabular}

Sumber: Output SPSS

\section{Analisis Regresi Berganda}

Tabel 3. Hasil Uji Regresi Berganda

\begin{tabular}{|l|c|c|}
\hline \multicolumn{1}{|c|}{ Jeni Pengujian } & TRR & BBPT \\
\hline Koefisien Determinasi (R ${ }^{2}$ ) & \multicolumn{2}{|c|}{0.082} \\
\hline Nilai R Square & 0.360 & 0.041 \\
\hline Uji Parsial (Uji t) & 0.045 & 0.580 \\
\hline Nilai Koefisien regresi & \multicolumn{2}{|c|}{0.604} \\
\hline Nilai Signifikansi & Uji Simultan (Uji F)
\end{tabular}

Sumber: Output SPSS

Berdasarkan tabulasi tiga hasil tes regresi berganda pertama memuat hasil uji koefisien determinasi dari nilai RSquare yang bernilai 0.082, perihal tersebut dapat diartikan bahwa variabel independen riset mampu menjelasakan senilai 8,2\% variabel dependen sementara untuk selebihnya sebesar $91.8 \%$ dipaparkan dengan variabel independen lain yang tidak termuat pada riset. Tes kedua adalah tes parsial. Pada variabel independen (BBPT) nilai sig 0,580, ini melebihi 0.05 sehingga variabel BBPT tidak memiliki pengaruh terhadap manajemen laba. Sedangkan pada variabel TRR memiliki nilai signifikansi 0.045 yang berarti variabel TRR memilik dampak untuk manajemen laba. Uji regresi berganda terakhir adalah tes simultan yang bertujuan mengetahui perencanaan pajak dan beban pajak tangguhan memiliki pengaruh kepada manajemen laba. Hasil uji ini bernilai 0.504 berarti untuk kedua variabel independen secara bersamaan tidak mempengaruhi manajemen laba.

Berdasarkan hasil uji statistik maka diperoleh persamaan regresi linear berganda sebagai berikut:

$$
\mathrm{SEC}=0.480+0.041 \mathrm{BBPT}+0.360 \mathrm{TRR}
$$

Dari persamaan regresi di atas dapat diketahui nilai konstanta sebesar 0.048 yang berarti apabila setiap masing-masing variabel independen dianggap tetap maka manajemen laba perusahaan meningkat 0.480 . Variabel beban pajak tangguhan memiliki nilai koefisien regresi 0.041 yang dapat diartikan bahwa setiap meningkatnya satu konstanta beban pajak tangguhan makan manajemen laba naik sebesar 0.041. Sedangkan untuk variabel perencanaan pajak (TRR) memiliki nilai 0.360 yang berarti setiap kenaikan satu konstanta perencanaan pajak maka manajemen laba naik sebesar 0.360 .

\section{Pengaruh Beban Pajak Tangguhan Terhadap Manajemen Laba}

Beban pajak tangguhan pada studi ini tidak berpengaruh pada manajemen laba. Beban pajak tangguhan yang merupakan pajak yang timbul akibat perbedaan pengakuan beban 


\section{Dita Rimbawati Dewi, Dian Anita Nuswantara}

ataupun pendapatan dari hasil perbedaan peraturan perpajakan dengan standar akuntansi (Pohan, 2013).Berkaitan dengan teori agensi yang menimbulkan selisih informasi mendorong manajer untuk bertindak oportunis dalam pengungkapan info. Manajer akan mengungkapkan informasi perusahaan kepada para pemangku kepentingan apabila ada manfaat pribadi bagi manajer, sedangkan jika tidak menguntungkan dirinya maka manajer akan menunda pengungkapan atau menyembunyikan informasi tersebut (Sulistyanto, 2014). Penundaan yang dilakukan dapat berupa penundaan pengakuan pendapatan atau beban sehingga menimbulkan beban pajak tangguhan.

Timbulnya saldo pajak tangguhan tidak berdampak dalam studi ini karena manajemen mempunyai keterbatasan dalam menetapkan saldo beban pajak tangguhan. Perihal ini disebabkan adanya aturan mengenai beban pajak tangguhan dalam akuntansi fiskal maupun akuntansi komersial yang telah diatur dalam peraturan perpajakan beban ataupun pendapatan yang boleh diakui dalam akuntansi fiskal. Sehingga manajemen laba tidak bisa dilakukan melalui beban pajak tangguhan (Prasetyo et al., 2018). Hal ini didukung dengan hasil penelitian Timuriana \& Muhamad (2015) yang mengemukakan beban pajak tangguhan tidak dapat mempengaruhi manajemen laba karena perusahaan-perusahaan yang mempergunakan celah untuk melaksanakan praktek manajemen laba dengan beban pajak tangguhan pada laporan keuangan fiskalnya akan tetap terkoreksi saat pemeriksaan fiskal. Batasan yang diberikan dari peraturan perpajakan lebih ketat dalam perhitungan pajak, yakni penghasilan atau biaya hanya diakui saat beban dikeluarkan dan saat pendapatan diterima sebagai dasar perhitungan laba rugi fiskal. Hal ini berarti perpajakan hanya mengakui beban pajak pada periode saat ini dan tidak mengakui adanya beban pajak tangguhan (Achyani \& Lestari, 2019). Beban pajak tangguhan hanya memiliki kemampuan dalam mencerminkan efek pajak yang timbul sebagai akibat beda temporer antara akuntansi dan pajak sehingga munculnya beban pajak tangguhan tdak dapat mendeteksi aktivitas manajemen laba yang dilakukan pihak manajemen (Septiana et al., 2016).

\section{Pengaruh Perencanaan Pajak Terhadap Manejemen Laba}

Perencanaan pajak memiliki pengaruh positif terhadap manajemen laba. Perencanaan pajak yang merupakan upaya manajemen untuk meminimalkan beban pajaknya tetapi tidak melanggar ketentuan perpajakan yang berlaku (Suandy, 2016). Pemenuhan tanggungan pajak dengan benar dan tidak mengganggu kelangsungan operasional perusahaan merupakan tujuan utama dari perencanaan pajak (Muljono, 2011). Hasil uji regresi berganda pada penelitian ini menghasilkan nilai signifikansi variabel perencanaan pajak 0.045 serta koefisien regresi 0.360 . Perihal tersebut diartikan perencanaan pajak mempengaruhi secara positif terhadap manajemen laba. Perencanaan pajak pada studi ini diukur dengan Effective Tax Rate yang juga seringkali digunakan manajer untuk acuan mengukur total pajak yang wajib dibayarakan perusahaan (Indradi \& Setyahadi, 2019). Perusahaan manufaktur yang memiliki kegiatan ekonomi lebih rumit daripada perusahaan nonmanufaktur dan perusahaan manufaktur terbagi dalam departemen-departemen menyebabkan agen atau manajemen tiap departemen memiliki motivasi tersendiri untuk menyejahterakan dirinya sendiri, dengan melakukan perencanaan pajak (Aditama \& Purwaningsih, 2014). Berkaitan dengan teori agensi yaitu hubungan antara pihak manajemen dan pemerintah. Hal ini menimbulkan konflik kepentingan antara pihak manajemen perusahaan dengan pemerintah sehingga mendorong pihak manajemen (agen) untuk melakukan perencanaan pajak. Perencanaan pajak dapat meminimalkan beban pajak membuat manajemen melakukan hal tersebut karena pajak sebagai unsur pengurangan laba bersih yang apabila laba bersih semakin kecil mencerminkan kinerja pihak manajemen. Upaya meminimalkan pembayaran pajak melalui perencanan pajak, laba perusahaan akan lebih maksimal karena pajak yang menjadi pengurang laba lebih rendah sehingga laba setelah pajak dapat optimum. Hasil studi ini sama dengan riset Dewi, Nuraina, \& Amah (2017) yaitu pajak 


\section{Dita Rimbawati Dewi, Dian Anita Nuswantara}

yang direncanakan berpengaruh. Pajak ialah salah satu bagian beban perusahaan yang mamput mengurangi laba (Pohan, 2013). Sehingga manajer melakukan upaya untuk meminimalkan pembayaran pajak tersebut dengan cara perencanaan pajak

\section{Kesimpulan}

Berdasarkan hasil pembahasan dan analisa yang telah dilakukan, maka dapat diperoleh kesimpulan sebagai berikut : 1) Beban pajak tangguhan tidak berpengaruh terhadap manajemen laba karena pada tes regresi berganda variabel independen (BBPT) nilai sig 0,580, ini melebihi 0.05 sehingga variabel BBPT tidak memiliki pengaruh terhadap manajemen laba. Hal ini juga dikarenakan pihak manajemen ada keterbatasan saat menentukan nilainya. Perihal itu disebabkan adanya aturan mengenai beban pajak tangguhan dalam akuntansi fiskal maupun akuntansi yang telah diatur dalam peraturan perpajakan beban ataupun pendapatan yang boleh diakui dalam akuntansi fiskal. Sehingga manajemen laba tidak bisa dilakukan melalui beban tangguhan pajak. 2) Hasil penelitian ini menunjukan tax planing memiliki pengaruh positif kepada manajemen laba karena variabel TRR memiliki nilai signifikansi 0.045 yang berarti kurang dari 0.05 sehingga dapat diartikan perencanaan pajak memiliki dampak untuk manajemen laba. Hal tersebut juga dikarenakan perencanaan laba dapat meminimalkan beban pajak yang membuat manajemen melakukan hal tersebut sebab pajak sebagai komponen pengurangan profit bersih apabila laba bersih semakin kecil mencerminkan kinerja pihak manajemen. Upaya meminimalkan pembayaran pajak melalui perencanan pajak, laba perusahaan akan lebih maksimal karena pajak yang menjadi pengurang laba lebih rendah sehingga laba setelah pajak dapat optimal.

Saran bagi peneliti selanjutnya yaitu dapat menambah jumlah pengambilan sampel yang dipergunakan agar hasil riset yang makin baik. Variabel-variabel yang telah diteliti perlu dipertimbangkan oleh peneliti selanjutnya apakah variabel tersebut dapat diikutsertakan kembali dalam penelitiannya. Disarankan pula untuk menggunakan proksi untuk mengukur variabel selain yang telah digunakan dalam riset ini serta dapat pula menambah variabel. Bagi pihak peruhasaan perlu mempertimbangkan variabel yang terbukti berpengaruh yaitu perencanaan pajak pada saat melakukan praktik manajemen laba.

\section{Daftar Pustaka}

Achyani, F., \& Lestari, S. (2019). Pengaruh Perencanaan Pajak Terhadap Manajemen Laba. Jurnal Akuntansi Dan Keuangan Indonesia, 4(1), 77-88.

Aditama, F., \& Purwaningsih, A. (2014). Pengaruh perencanaan pajak terhadap manajemen laba pada perusahaan nonmanufaktur yang terdaftar di bursa efek indonesia. MODUS, 26(1), 33-50.

Astutik, R. E. P. (2016). Pengaruh Perencanaan Pajak dan Beban Pajak Tangguhan Terhadap Manajemen Laba. Jurnal Ilmu \& Riset Akuntansi, 5(3).

Astutik, R. E. P., \& Mildawati, T. (2016). Pengaruh Perencanaan Pajak Dan Beban Pajak Tangguhan Terhadap Manajemen Laba. Jurnal Ilmu Dan Riset Akuntansi, 5(3), 1-17. https://doi.org/10.31328/jopba.v1i01.79

Barus, A. C., \& Setiawati, K. (2015). Pengaruh Asimetri Informasi, Mekanisme Corporate Governance dan Beban Pajak Tangguhan Terhadap Manajemen Laba. Jurnal Wira Ekonomi Mikroskil, 5(1), 31-40.

Cohen, D. A., Dey, A., \& Lys, T. Z. (2005). Trends in Earnings Management and Informativeness of Earnings Announcements in the Pre- and Post-Sarbanes Oxley Periods. SSRN Electronic Journal, 847. https://doi.org/10.2139/ssrn.658782

Cooper, D. R., \& Schindler, P. S. (2014). Business Research Methods (12th ed.). MC Graw 
Hill.

Dewi, E. R., Nuraina, E., \& Amah, N. (2017). Pengaruh Tax Planning dan Ukuran Perusahaan Terhadap Manajemen Laba (Studi Empiris Pada Perusahaan Property yang Terdaftar di Bursa Efek Indonesia). FIPA: Forum Ilmiah Pendidikan Akuntansi, 5(1), 854-881.

Dyreng, S., Hanlon, M., \& Maydew, E. L. (2011). Where Do Firms Manage Earnings ? Review of Accounting Studies, 17(3).

Fahmi, I. (2013). Pengantar Manajemen Keuangan. Alfabeta.

Febrian, R., Wahyudi, T., \& Subeki, A. (2018a). Analisis Pengaruh Perencanaan Pajak dan Beban Pajak Tangguhan terhadap Manajemen Laba (Studi Kasus pada Perusahaan Manufaktur yang Tercatat Di Bursa Efek Indonesia). Akuntabilitas: Jurnal Penelitian Dan Pengembangan Akuntansi, 12(2), 145-160.

Febrian, R., Wahyudi, T., \& Subeki, A. (2018b). Analisis Pengaruh Perencanaan Pajak dan Beban Pajak Tangguhan Terhadap Manajemen Laba (Studi Kasus Pada Perusahaan Manufaktur Yang Tercatat Di Bursa Efek Indonesia). AKUNTABILITAS: Jurnal Penelitian Dan Pengembangan Akuntansi, 12(2), 145-160. https://doi.org/10.29259/ja.v12i2.9314

Ghozali, I. (2016). Aplikasi Analisis Multivariate Dengan Program IBM SPSS 23 (8th ed.). Badan Penerbit Universitas Diponegoro.

Harnanto. (2013). Perencanaan Pajak. BFFE.

Indradi, D., \& Setyahadi, M. M. (2019). Pengaruh Transaksi Hubungan Istimewa Terhadap Tarif Pajak Efektif dengan Leverage sebagai Variabel Moderating. Jurnal Akuntasni Berkelanjutan Indonesia, 2(3), 375-392.

Jensen, M. C., \& Meckling, W. H. (1976). Theory of the Firm : Managerial Behavior, Agency Costs and Ownership Structure Theory of the Firm : Managerial Behavior, Agency Costs and Ownership Structure. Journal of Financial Economics, 3, 305-360.

Khotimah, H. (2014). Pengaruh Perencanaan Pajak terhadap Manajemen Laba. Jurnal Bisnis Dan Manajemen, 4(2), 170-180.

Kisno, \& Istianingsih. (2016). Detections Earnings Management by Deferred Tax Expense and Firm Characteristic. Jurnal Riset Akuntansi Terpadu, 9(1), 139-145.

Lestari, F. A. P. (2018). Pengaruh Profitabilitas dan Beban Pajak Tangguhan Terhadap Manajemen Laba. Sosio E-Kons, 10(3), 270-278.

Lisa, O. (2012). Asimetri Informasi Simetri Informasi dan Manajemen Laba. Jurnal WIGA: Jurnal Penelitian Ilmu Ekonomi, 2(1), 42-49.

Lubis, I., \& Suryani. (2018). Pengaruh Tax Planning, Beban Pajak Tangguhan dan Ukuran Perusahaan Terhadap Manajemen Laba (Studi Empiris pada Perusahaan Industri Barang Konsumsi di Bursa Efek Indonesia Tahun 2012-2016). Jurnal Akuntansi Dan Keuangan, $7(1), 41-58$.

Mahpudin, E. (2017). Pengaruh Perencanaan Pajak Terhadap Manajemen Laba Pada Perusahaan Yang Termasuk Dalam Jakarta Islamic Index. Accounthink: Journal of Accounting and Finance, 2(02), 389-403. https://doi.org/10.35706/acc.v2i02.916

Muljono, D. (2011). Tax Planning: Menyiasati Pajak dengan Bijak (1st ed.). ANDI.

Nugraha, N. B., \& Meiranto, W. (2015). Pengaruh Corporate Social Respondibility, Ukuran Perusahaan, Profitabilitas, Leverage dan Capital Intensity Terhadap Agresivitas Pajak (Studi Empiris pada Perusahaan Non Keuangan yang Terdaftar di Bursa Efek Indonesia 2012-2013). Diponegoro Journal of Accounting, Vol. 4 No., 1-14. http://ejournals1.undip.ac.id/index.php/accounting

Nurhandono, F., \& Firmansyah, A. (2017). Lindung Nilai, Financial Leverage, Manajemen Laba Dan Agresivitas Pajak. Jurnal Media Riset Akuntansi, Auditing \& Informasi, 17(1), 31-52. 
Phillips, J., Pincus, M., \& Rego, S. O. (2003). Earnings Management: New Evidence Based on Deferred Tax Expense. The Accounring Review, 78(2), 491-521.

Pohan, C. A. (2013). Manajemen Perpajakan: Strategi Perencanaan Pajak dan Bisnis. Gramedia Pustaka Utama.

Prabowo, S. (2020). Menyelaraskan Standar Akuntansi dengan Peraturan Pajak. Majalah Pajak. https://majalahpajak.net/menyelaraskan-standar-akuntansi-dengan-peraturanpajak/

Prasetyo, N. C., Riana, \& Masitoh, E. (2018). Pengaruh Perencanaan Pajak, Beban Pajak Tangguhan dan Kualitas Audit Terhadap Manajemen Laba. MODUS, 31(2), 156-171.

Richardson, V. J. (1998). Information Asymetry and Earnings Management: Some Evidence.

Sandy, S., \& Lukviarman, N. (2015). Pengaruh corporate governance terhadap tax avoidance: Studi empiris pada perusahaan manufaktur. Jurnal Akuntansi \& Auditing Indonesia, 19(2), 85-98. https://doi.org/10.20885/jaai.vol19.iss2.art1

Santana, D. K. W., \& Wirakusuma, M. G. (2016). Pengaruh Perencanaan Pajak, Kepemilikan Manajerial Dan Ukuran Perusahaan Terhadap Praktik Manajemen Laba. E-Jurnal Universitas Udayana, 14(3), 1555-1583. https://doi.org/10.37932/j.e.v8i2.40

Scott, W. R. (2000). Financial Accounting Theory. Prestice Hall.

Septiana, W. I., Sofianty, D., \& Fadilah, S. (2016). Pengaruh Tax Planning Dan Beban Pajak Tangguhan Terhadap Manajemen Laba. Prosiding Akuntansi, 2(2), 402-408.

Suandy, E. (2016). Perencanaan Pajak. Salemba Empat.

Sugiyono. (2011). Metode Penelitian Kuantitatif, Kualitatif dan $R \&$ D (p. 11). Alfabeta.

Sulistyanto, S. (2014). Manajemen Laba: Teori dan Model Empiris. Grasindo.

Sumomba, C. R., \& Hutomo, Y. S. (2012). Pengaruh Beban Pajak Tangguhan dan Perencanaan Pajak Terhadap Manajemen Laba. KINERJA, 16(2), 103-115.

Timuriana, T., \& Muhamad, R. R. (2015). Pengaruh Aset Pajak Tangguhan dan Beban Pajak Tangguhan Terhadap Manajemen Laba. JIAFE: Jurnal Ilmiah Akuntansi Fakultas Ekonomi, 1(2), 12-20.

Wareza, M. (2019). Tiga Pilar dan Drama Penggelembungan Dana. CNBC Indonesia. https://www.cnbcindonesia.com/market/20190329075353-17-63576/tiga-pilar-dandrama-penggelembungan-dana

Wibisono, H. (2014). Pengaruh Manajemen Laba terhadap Kinerja Perusahaan di Seputar Seasoned Equity Offering. Jurnal Akuntansi, 1(1).

Yunila, F., \& Aryati, T. (2018). Pengaruh Perencanaan Pajak dan Pajak Tangguhan Terhadap Manajemen Laba dengan Kualitas Audit sebagai Variabel Moderasi. Seminar Nasional Cndekiawan Ke 4 Tahun 2018, 2(2), 1021-1027. 


\section{INOBIS: JURNAL INOVASI BISNIS DAN MANAJEMEN INDONESIA}

\section{DITERBITKAN OLEH:}

Pengurus Forum Inovasi Bisnis dan Manajemen (INOBIS) Mulai diterbitkan sejak tahun 2017

Frekuensi Penerbitan: Maret, Juni, September, Desember

\section{ARTIKEL TEMA RISET:}

Manajemen Pemasaran, Manajemen Keuangan, Manajemen SDM, Manajemen Operasi / Rantai Pasok, Sistem Informasi Manajemen, serta Kewirausahaan \& Manajemen UMKM.

Jurnal Inovasi Bisnis dan Manajemen Indonesia (INOBIS), diterbitkan oleh Pengurus Forum Inovasi Bisnis dan Manajemen (INOBIS), secara berkala empat kali dalam setahun.

Jurnal INOBIS bertujuan untuk menyebarluaskan hasil penelitian di bidang manajemen dan bisnis kepada para akademisi, praktisi, mahasiswa dan pihak yang berminat. Jurnal INOBIS menerima kiriman artikel yang ditulis dalam bahasa Indonesia maupun bahasa Inggris.

Penulis harus menyatakan bahwa artikel yang dikirim ke Jurnal INOBIS tidak dikirim atau dipublikasikan ke jurnal lain.

Penentuan artikel yang dimuat di Jurnal INOBIS melalui proses review oleh tim dewan redaksi Jurnal INOBIS dengan mempertimbangkan antara lain: terpenuhinya persyaratan baku publikasi jurnal, metode riset yang digunakan, signifikansi, dan kontribusi hasil penelitian terhadap keilmuan manajemen.

\section{ALAMAT REDAKSI}

PENGURUS FORUM INOVASI BISNIS DAN MANAJEMEN INOBIS

(1) http://jurnal.inobis.org/

$凶$ inobis.info@gmail.com

이 @ InobisOfficial 


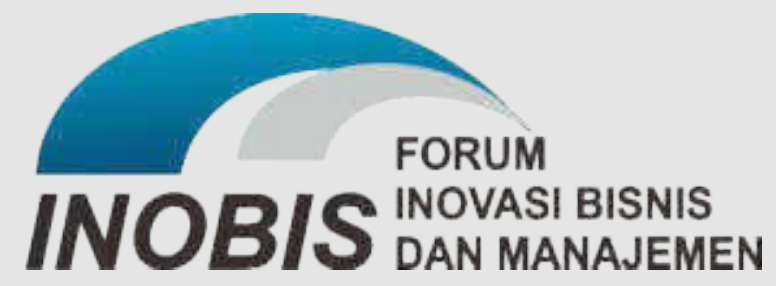

